\title{
MEME SEBAGAI CERMINAN BERPIKIR KRITIS WARGANET DI RUANG SIBER (KAJIAN SEMIOTIK PRAGMATIK)
}

\author{
Prapti Wigati Purwaningrum¹, Aceng Ruhendi Saifullah ${ }^{2}$, Dadang Sudana ${ }^{3}$ \\ Program Studi Linguistik, Universitas Pendidikan Indonesia \\ ${ }^{1}$ tiwinurulhuda84@gmail.com, ${ }^{2}$ acengruhendisaifullah@upi.edu, ${ }^{3}$ dsudana2013@yahoo.com
}

\begin{abstract}
Abstrak
Isu pemindahan ibu kota sudah menjadi wacana dari beberapa pemerintahan sebelumnya. Namun, pada era kepemimpinan saat ini diumumkan secara resmi tentang niatan tersebut. Tepat sekitar Agustus lalu presiden mengumumkan secara resmi tentang pemindahan ibu kota dan sekaligus lokasi yang strategis untuk dijadikan ibu kota baru. Sebagai bentuk pro dan kontra muncul berbagai tanggapan dari masyarakat. Meme merupakan salah satu bentuk tanggapan yang paling sering muncul di dunia siber khususnya media sosial sebagai bentuk tanggapan atas kebijakan ini. Penelitian ini merupakan studi kasus yang menggunakan meme dan tanggapan warganet sebagai data penelitian. Untuk memahami tanda dan makna serta tanggapan dari warganet melalui teori multimodal, semiotik pragmatik, kebebasan berekspresi, dan berpikir kritis. Melalui penelitian ini penulis ingin mengetahui bagaimana tanda, makna serta tanggapan warganet yang muncul dalam meme merupakan bentuk perkembangan berpikir kritis terhadap sebuah kebijakan pemerintah. Dalam kajian ini pengumuman resmi dari presiden tentang "pemindahan ibu kota" dimaknai sebagai tanda, sedangkan pemunculan berbagai meme terkait, dimaknai sebagai reaksi masyarakat untuk menunjukkan pro dan kontra atas keputusan tersebut. Melalui pemunculan meme, warganet mencoba untuk berekspresi, berpendapat, serta mengkritik terhadap kebijakan pemerintah tentang pemindahan ibu kota. Pada akhirnya temuan dari analisis ini akan mendeskripsikan tentang bagaimana pola berpendapat, berkomentar, dan berpikir kritis di ruang siber.
\end{abstract}

Kata Kunci: Semiotik-pragmatik, tanda dan makna, berpikir kritis, meme

\begin{abstract}
The issue of moving the capital has become a discourse from several previous governments. But in the current era of leadership was officially announced about the intention. Right around last August the president officially announced the relocation of the capital and at the same time a strategic location to become a new capital. As a form of pros and cons emerged various responses from the public. Meme is one of the most common forms of response in cyberspace especially social media as a form of response to this policy. This research is a case study using memes and citizens' responses as research data. To understand signs and meanings and responses from citizens through, semiotics pragmatic, freedom of expression, and critical thinking. Through this research the writer wants to know how the signs, meanings and responses of citizens who appear in memes are a form of development of critical thinking on a government policy. In this study the official announcement from the president about "moving the capital" was interpreted as a sign while the appearance of various related memes was interpreted as a public reaction to show the pros and cons of the decision. Through the appearance of memes, citizens try to express, argue, and criticize government policies regarding the relocation of the capital city. Finally, the findings of this analysis will describe how patterns of opinion, commenting, and critical thinking in cyberspace.
\end{abstract}

Keywords: semantics, pragmatics, critical thinking, and meme 


\section{PENDAHULUAN}

Seiring dengan perkembangan teknologi yang semakin canggih, semakin memberikan kemudahan pada masyarakat untuk berkomunikasi, memperoleh berbagai macam informasi, bahkan untuk hanya sekadar menunjukkan eksistensi diri. Dalam hal ini internet sangat berperan di dalamnya, di antaranya memberikan segala kemudahan. Dengan perubahan seperti itu, maka berpengaruh juga pada cara masyarakat berkomunikasi sehingga muncul interaksi di ruang siber dengan masyarakat atau warganet. Melalui ruang siber segala bentuk pemikiran, ide, konsep serta cita-cita dapat disampaikan melalui sebuah teknologi yang diperkenalkan oleh (Dahlberg, 2006) yang disebut Computer Mediated Communication.

Segala bentuk interaksi di dunia siber dilakukan dengan menggunakan media CMC. Salah satu interaksi yang saat ini marak terjadi di dunia siber adalah berupa sindiran dan kritikan terhadap suatu fenomena seperti kebijakan pemerintah, kelakuan sesorang yang mungkin dirasa out of the box maka akan sangat mudah tersebar di ruang siber. Di ruang siber ini siapa pun bebas mengunggah, memberi komentar, mengunggah ulang dan seterusnya. Dalam hal ini peranan media sudah terhenti dan hanya berlanjut adanya interaksi antar warganet dan terjadi sebuah diskusi panjang melalui saling melempar komentar. Seperti dalam penelitian yang telah dilakukan oleh (Saifullah, 2016) menyimpulkan bahwa saat ini segala bentuk wacana interaktif di dunia siber merupakan sebuah forum demokratisasi, karena segala bentuk teks merupakan milik dan hak warganet untuk membuat dan mengomentarinya.

Saat ini khususnya di tahun politik, mulai dari pemilihan gubernur yang dilaksanakan secara serentak, berlanjut pada pemilihan presiden di awal tahun 2019 lalu, hingga sebelum masa jabatan presiden berakhir, Presiden Republik Indonesia mengumumkan secara resmi rencana pemindahan ibu kota ke Provinsi Kalimantan semakin menambah deretan isu politik yang semakin menarik untuk diperbincangkan bahkan diperdebatkan. Saat ini perdebatan dan perbincangan tidak hanya di forum resmi, tetapi sudah banyak beralih ke ruang siber. Di ruang ini warganet bebas berpendapat bahkan mengkritik terhadap sebuah kebijakan. Cara penyampaian kritik pun kini telah banyak mengalami perkembangan, salah satunya melalui sebuah humor yang sifatnya satir. Masing-masing berlomba saling memberikan tanggapan baik bentuk pro maupun kontra. Melalui kreativitas yang tinggi para kreator menciptakan meme. Meme merupakan bentuk humor digital dan sangat lekat dengan sindiran atau yang sering disebut dengan humor satir. Meme pertama kali telah diperkenalkan oleh (Dawkins, 2006) dalam bukunya yang menyebutkan bahwa meme merupakan bentuk gagasan, perilaku, gaya yang sifatnya menyebar dari satu orang ke yang lainnya. Dalam penyebarannya meme sangat bergantung pada internet atau ruang siber, karena melalui media ini meme dapat menyebar bahkan viral. Pemunculan meme biasanya dilatarbelakangi oleh sebuah kejadian atau fenomena, pengemasan meme pun dibalut dengan humor dan tuturan yang cukup menggelitik, tetapi dapat dipastikan makna tersirat dari sebuah meme merupakan sindiran dan kritikan.

Kajian tentang media sosial saat ini sudah lumayan banyak dengan ranah yang bervariasi. Berikut beberapa penelitian yang relevan Misalnya pada (Susanti, 2015), dalam kajiannya menyimpulkan bahwa dalam media sosial seperti twitter menjadi sebuah forum atau sebagai sebuah media yang efektif untuk menyampaikan sebuah pesan dan sekaligus memberikan respons atau komentar. Penelusuran lain dari penelitian sebelumnya adalah (Zubaidah dkk., 2018) dalam kajiannya mengamati tentang keberadaan meme di media sosial saat ini. Dalam simpulannya meme yang 
berupa gambar dan teks tanpa melibatkan kolom komentar pun saja sudah tidak hanya sekadar menyajikan humor semata, tetapi membawa pesan tersirat yang merepresentasikan sesuatu seperti menyindir, mengkritik bahkan untuk menjatuhkan citra seseorang atau kelompok. Perkembangan media sosial saat ini sudah sangat luas, hal ini tidak lepas peran warganet yang begitu kreatif serta kritis dalam mengunggah informasi dalam teks maupun gambar termasuk meme. Sudarsono menyimpulkan dalam tulisannya tentang meme yang beredar di media sosial saat ini dapat membentuk dan menimbulkan prasangka sehingga tidak jarang masing-masing individu atau kelompok dapat terpancing. Selain itu, sebuah meme terkadang juga mampu berperan sebagai pengingat atau kritik agar selalu bersikap jujur dalam hal apa pun (Sudarsono, 2017).

Munculnya meme di berbagai media sosial di ruang siber khususnya di tahun politik maka semakin banyak. Menurut (Ross \& Rivers, 2019) dalam salah satu simpulannya menyatakan bahwa meme di internet sebagai wujud perluasan bingkai di media yang sangat berpengaruh terhadap fenomena tertentu. Selain itu, meme disampaikan melalui balutan humor yang mampu mewakili partisipasi sosial politik di ruang siber. Banyak hal yang dapat dikritisi melalui sebuah meme, dalam hal ini termasuk juga pemerintah, setiap langkah dan kebijakan yang dilakukan tidak luput dari sorot media sosial. Yang baru-baru ini terjadi adalah pengumuman resmi presiden atas rencana pemindahan ibu kota ke Provinsi Kalimantan. Pada 29 Agustus 2019 Presiden Republik Indonesia mengumumkan tentang perpindahan ibu kota, pidato ini disampaikan di akun YouTube secretariat presiden, melalui link YouTube yang diunggah oleh secretariat presiden berjudul (Upcoming LIVE | Presiden Jokowi Mengumumkan Ibu Kota Baru, 2019). Muncul berbagai tanggapan pro dan kontra serta ada yang berusaha bersikap netral. Melalui dunia siber terjadi perkembangan cara bersikap kritis. Wujud kritik para warganet melalui penciptaan meme satire yang diunggah di media sosial Instagram dan facebook lalu ditanggapi oleh warganet lainnya, dan akhirnya terjadi interaksi antarwarganet, seperti dalam pendapat (Berger, 1997), bahwa sebuah satir selalu memiliki fungsi kritik. Media sosial di Indonesia mengalami perkembangan yang sangat pesat, jika dulu hanya ada Friendster dan facebook maka sekarang telah muncul Path, Instagram, Twitter yang warganet bebas memberikan tanggapan tentang banyak hal sehingga mencapai trending topic.

Melalui penelitian ini penulis ingin mengetahui bagaimana tanda, makna yang muncul dalam meme merupakan bentuk perkembangan berpikir kritis warganet terhadap sebuah kebijakan pemerintah. Dalam kajian ini pengumuman resmi dari presiden tentang "pemindahan ibu kota" dimaknai sebagai tanda, sedangkan pemunculan berbagai meme terkait, dimaknai sebagai reaksi masyarakat untuk menunjukkan pro dan kontra atas keputusan tersebut di dunia siber salah satunya media sosial Instagram.

\section{METODE PENELITIAN}

Dalam penelitian penulis memilih menggunakan perspektif kualitatif serta semiotik pragmatik, dengan tujuan untuk menjabarkan keadaan saat ini khususnya setelah diumumkannya tentang rencana pemindahan ibu kota ke provinsi Kalimantan serta berbagai tanda yang muncul di dalamnya. Berbagai reaksi pro dan kontra dari masyarakat, salah satunya munculnya berbagai meme satir yang ditujukan sebagai bentuk reaksi yang bersifat kritik pada rencana tersebut. Data berupa meme dengan tema pemindahan ibu kota yang ada di media sosial Instagram dan Facebook, sedangkan untuk mengupas dibalik tanda dan makna pada meme tersebut, penulis 
menggunakan pemikiran dari Peirce mengidentifikasi melalui ketiga tanda sebagai representatif. Ketiga tanda tersebut adalah ikon, simbol, dan indeks. Tanda dan makna dalam meme yang muncul sebagai reaksi dari sebuah aksi rencana pemindahan ibu kota akan dianalisis lalu dikaitkan sebagai cerminan sikap kritis warganet di ruang siber sehingga hasil penelitian ini berupa penjabaran data berdasarkan fenomena yang muncul di ruang siber bukan berupa data statistik Wray, Trott, Bloomer 2009 dalam (Saifullah, 2019). Ada tiga tahap dalam menafsirkan tanda, pertama aspek representament diterima oleh panca indera, selanjutnya diinformasikan melalui kognisi berupa objek, terakhir menafsirkan objek tersebut sesuai keinginan, (Hoed, 2011). Ikon diartikan sebagai tanda yang menyerupai objek, simbol tanda yang muncul sebagai kebiasaan, di antaranya tanda konvensional yaitu tanda muncul untuk menggantikan sesuatu, tanda yang bersifat aksidental yaitu tanda yang sering dimaknai secara personal, simbol universal, simbol ini muncul sebagai hasil kesepakatan bersama, berikutnya indeks, diartikan sebagai sebuah tanda yang muncul adanya sebab akibat.

Data utama kajian ini adalah meme dengan tema "pemindahan ibu kota" yang muncul di beberapa media sosial Instagram @fakartun sebagai reaksi dari warganet atas pengumuman rencana pemindahan ibu kota yang diumumkan oleh Presiden Republik Indonesia. Beberapa meme dengan tema "pemindahan ibu kota, dalam kajian ini akan ditampilkan tiga buah meme sebagai representasi data. Pengambilan data berdasarkan munculnya meme tersebut pada akun @fakartun dalam kurun waktu 29 Agustus 2019 sejak diumumkannya rencana pemindahan ibu kota oleh Presiden Republik Indonesia hingga sekitar Oktober 2019.

\section{HASIL DAN PEMBAHASAN}

Berikut tiga meme dari akun @fakartun yang digunakan sebagai representasi data yang beredar setelah pengumuman resmi tentang rencana pemindahan ibu kota pada tanggal 29 Agustus 2019 hingga Oktober 2019. Ketiga meme ini cukup mewakili kemunculan beberapa meme yang mengindikasikan cerminan berpikir kritis waganet di ruang siber.

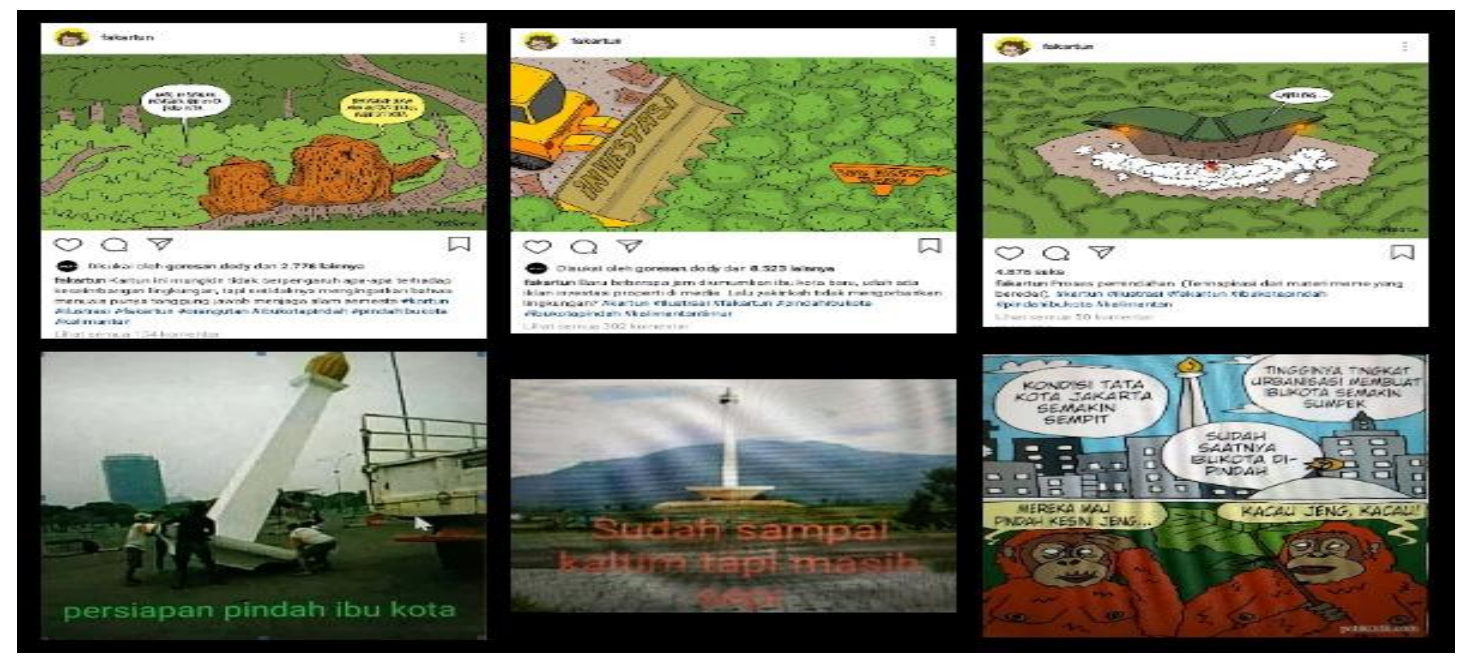

Gambar 1 Meme "Pemindahan Ibukota" di media sosial Fakartun Instagram (representasi kritik) 


\section{Cerminan Beripikir Kritis Warganet Dalam Meme Pemindahan Ibukota}

Pendapat tentang berpikir kritis menurut Rosenbaum, Beentjes, \& Konig, 2008 dalam (Ku et al., 2019) kemampuan berpikir kritis memainkan peran yang sangat penting dalam literasi media berita yang melibatkan pengetahuan dan kemampuan untuk memikirkan kualitas berita yang dihasilkan dari pengetahuan berikut. Cerminan berpikir kritis warganet berkaitan dengan kebijakan pemerintah dalam rangka pemindahan ibu kota yang telah disampaikan oleh Presiden Republik Indonesia pada 29 Agustus 2019 mengundang berbagai tanggapan warganet. Hal yang sangat dikritisi adalah tentang pemindahan ibu kota itu sendiri, kebijakan ini bergulir bersamaan dengan keadaan perekonomian sedang terombang-ambing. Meme yang muncul seiring dengan perkembangan fenomena yang sedang terjadi saat itu sehingga saat menafsirkan meme tersebut maka harus memiliki wawasan tentang keduanya, agar meme yang ditampilkan dengan balutan humor dapat dinikmati dan sekaligus memahami implikasi di balik meme tersebut.

Berikut cuplikan pidato resmi Presiden Republik Indonesia mengenai rencana pemindahan ibukota yang ditayangkan melalui saluran youtube yang diunggah oleh sekretariat presiden dengan judul (Upcoming LIVE | Presiden Jokowi Mengumumkan Ibu Kota Baru, 2019):

"pada kesempatan yang bersejarah ini, dengan memohon ridho Allah SWT, dengan meminta ijin dan dukungan dari bapak ibu anggota dewan yang terhormat, para sesepuh dan tokoh bangsa terutama dari seluruh rakyat Indonesia, dengan ini saya mohon izin untuk memindahkan ibukota negara kita ke pulau Kalimantan"

Penggalan tuturan presiden dalam pidato resmi kenegaraan di atas merupakan sebuah tanda yang dimunculkan oleh seorang kepala negara tentang sebuah kebijakan sekaligus sebagai keputusan untuk segera memindahkan ibu kota ke Pulau Kalimantan. Pascapengumuman tersebut muncul berbagai meme satir yang mengkritisi keputusan tersebut. Pemunculan meme dalam hal ini dapat dimaknai sebagai reaksi dari sebuah tanda yang telah dimunculkan sebelumnya yaitu pidato pengumuman pemindahan ibu kota ke Kalimantan.

Pada meme (1) terdapat ikon yaitu tanda-tanda yang menyerupai objek daun, pohon, orang hutan sebagai penghuni hutan di Kalimantan diintepretasikan sebagai keadaan hutan di wilayah Kalimantan saat-saat akan adanya pemindahan ibu kota, sedangkan tuturan yang ada dalam meme tersebut sebagai simbol konvensional sebagai tanda untuk menggantikan sesuatu. Dalam meme tersebut tuturan "dan di sinilah rencana ibu kota baru kita" dan "berharap juga ada hutan baru habitat kita" menggantikan sesuatu yaitu ungkapan atas apa yang dirasakan oleh makhluk hidup direpresentasikan dengan orang hutan sebagai penghuni hutan Kalimantan, hal ini dapat diartikan, hewan saja dapat merasakan kesedihan akan kehilangan tempat tinggal bagaimana dengan manusia. Meme (2) terdapat tanda yang menyerupai objek kendaraan berat berupa traktor yang sekaligus menjadi simbol universal, simbol tersebut memiliki kesepakatan sebagai sebuah alat berat untuk mengeruk dan meratakan bangunan atau lahan. Namun, yang sedikit mengecewakan, di tengah rencana pemindahan ibu kota, alat tersebut digunakan untuk mengeruk atau meratakan tanah bukan untuk infrastruktur melainkan untuk investasi, hal ini terlihat dari simbol universal yang muncul pada tulisan di traktor "investasi", kata tersebut memiliki kesepakatan bersama digunakan untuk menyatakan sebuah proyek investasi yang tujuannya untuk dikomersilkan. Meme 
(3) ikon berupa rumput hijau dan sebuah benda menyerupai gedung dewan, jika dikaitkan dengan konteks tentang pemindahan ibu kota, maka meme ini sangat relevan. Satu per satu gedung di Jakarta dipindahkan, salah satunya gedung DPR yang menyerupai uvo dan mendarat di dataran berumput hijau yang menyimbolkan bahwa daerah tersebut belum siap secara fisik, masih butuh dirapikan. Meme (4) gambar tugu monas merupakan tanda yang menyerupai objek sebagai ikon dan kebanggaan dari kota Jakarta, beberapa orang yang mewakili tanda masyarakat dalam meme tersebut yang sedang bersusah payah mengangkat tugu monas untuk dibawa ke Kalimantan. Selain itu, terdapat juga ikon yang mewakili suasana kota Jakarta menjelang perpindahannya ke Kalimantan, hal ini terlihat pada meme tersebut seperti hanya ada satu gedung, padahal Jakarta dikenal dengan gedung-gedung pencakar langit. Selain itu, terdapat juga tampilan langit yang terlihat kelabu, ini merupakan sebuah simbol sebagai kesepakatan bersama jika langit kelabu, tidak cerah maka akan turun hujan dan jika dikaitkan dengan konteks pemindahan ibu kota adanya kesedihan, kecemasan hingga tugu monas sebagai ciri khas kota Jakarta pun akan ikut dipindahkan. Meme berikutnya (5) memunculkan kembali gambar tugu monas, tetapi sudah sampai di suatu tempat yang jika sesuai konteks adalah Kalimantan yang terkenal dengan hutan dan lahan yang hijau serta subur. Namun, pada meme tersebut terdapat tuturan "sudah masuk Kalimantan tapi masih sepi" merupakan bentuk satir terhadap kesiapan pemerintah serta lahan untuk menjadi tempat pemindahan ibu kota baru karena lahan masih berupa tanah pertanian yang sama sekali belum ada infrastruktur pendukung sebagai sebuah ibu kota. Meme (6) ada dua gambar atas dan bawah, atas menggambarkan keadaan ibu kota yang sudah padat dengan gedung pencakar langit, serta terdapat tuturan "kondisi tata kota Jakarta semakin sempit", "tingginya tingkat urbanisasi membuat ibu kota semakin sumpek", dua tuturan tersebut merupakan sebagian dari alasan pemindahan ibu kota, dan "sudah saatnya ibu kota dipindah" mengimplikasikan terhadap solusi yang ditawarkan dan telah ditetapkan pada tanggal 29 Agustus 2019 oleh pemerintah. Namun, pada gambar di bawahnya direpresentasikan melalui gambar orang hutan yang sedang bercakap-cakap dengan penuh kecemasan berkaitan dengan pemindahan ibu kota terlihat pada tuturan "mereka mau pindah kesini jeng" dan dijawab dengan "kacau jeng kacau". Dari tuturan tersebut mengimplikasikan bahwa ada pihak-pihak yang merasa dirugikan atas pemindahan ibu kota. Dalam meme ini digambarkan dengan orang hutan yang akan kehilangan habitatnya yaitu hutan karena Provinsi Kalimantan sangat terkenal dengan hutan yang lebat, jika benar pemindahan ibu kota terjadi pasti akan ada lahan atau hutan yang diubah menjadi gedung atau infrastruktur lain.

\section{Keterlibatan warganet dalam diskusi politik pada kolom komentar di ruang siber}

Saat ini humor satir dalam bentuk meme di ruang siber mengalami berkembangan yang begitu pesat, hal ini terlihat dari makin seringnya meme satir muncul seiring dengan fenomena tertentu. Meme ini begitu mudah menyebar khususnya di media sosial salah satunya Instagram. Pemunculan meme ini dapat dikatakan sebagai kreativitas yang juga sekaligus kepekaan seorang kreator terhadap sesuatu, tetapi ternyata tidak terhenti sampai di situ, melalui unggahan meme di media sosial dapat memancing berbagai reaksi dari warganet. Tanggapan dari warganet yang beragam secara tidak langsung menciptakan sebuah suasana keterbukaan, karena di sinilah siapa pun berhak berkomentar dan berasumsi tanpa batas.

Meme satir sudah diperkenalkan sejak lama (Shifman, 2013) dalam tulisannya menyatakan bahwa meme telah berkembang di dunia digital dan mengalami 
perkembangan dan penyebaran yang sangat cepat. Sebelumnya (Shifman, 2007) menyebutkan bahwa humor berbasis internet merupakan ide lain yang muncul dari berbagai komunikasi yang bersifat humor. Pemunculan meme sebagai humor satir telah berkembang di Indonesia khususnya di media sosial. Di tengah maraknya isu-isu berpayung politik, meme satir menjadi salah satu alat bagi warganet untuk terlibat dalam diskusi politik. Hal ini tercermin dalam semakin banyaknya muncul meme sebagai reaksi terhadap sebuah fenomena yang berkembang di masyarakat. Salah satunya tentang rencana pemerintah tentang pemindahan ibu kota, Presiden Republik Indonesia telah mengumumkan secara resmi dan menentukan provinsi tujuan. Berbagai reaksi dari warganet bermunculan salah satunya melalui meme dengan berbagai gambar lucu serta tuturan di dalamnya yang memunculkan humor saat menikmati, tetapi cukup mengena.

Beberapa meme satir berbalut kepentingan politik, bahkan saat pilpres 2019 banyak sekali warganet yang memberikan dukungan dan tidak sedikit menunjukkan sikap berseberangan secara terang terangan melalui meme satir. Hal ini berlanjut hingga menjelang berakhirnya masa jabatannya, Presiden Republik Indonesia mengumumkan rencana pemindahan ibu kota. Dari keenam meme satir tentang pemindahan ibu kota yang ditunjukkan dengan berbagai tanda verbal dan visual yang mencakup adanya ikon dan simbol mampu mengomunikasikan adanya kritik terhadap rencana pemindahan ibu kota di tengah isu politik lainnya.

Tanda-tanda yang muncul dalam meme satir "pemindahan ibu kota" yang melibatkan dua tempat yaitu Jakarta dan Kalimantan maka sebagai ikon dimunculkan dengan tugu monas, gedung pencakar langit, gedung dewan, hutan lebat, orang hutan, tanah yang luas, dan bebas polusi, sedangkan untuk simbol dalam meme satir "pemindahan ibu kota dimunculkan dengan teks dalam meme tersebut yang dikemas dengan sederhana, mudah dipahami, dan memiliki nilai humor, sedangkan indeks muncul pada meme tersebut yang menginterpretasikan kritik sebagai reaksi dari apa yang telah disampaikan presiden Republik Indonesia mengenai pemindahan ibu kota.

Kepopuleran meme semakin berkembang karena gambar dan Bahasa meme dikemas secara sederhana, mudah dipahami dan mengandung humor. Humor dalam meme dimunculkan oleh seorang kreator yaitu warganet yang memiliki kreativitas dan sikap kritis sebagai penanggap sebuah fenomena, lalu digulirkan dalam media sosial untuk mengomunikan berbagai isu yang sedang berkembang. Hal ini menciptakan keterlibatan warganet dalam berbagai sikap politik termasuk untuk mengkritisi terhadap kebijakan pemerintah. Semenjak digulirkannya sebuah meme yang salah satunya mengkritisi sebuah kebijakan pemerintah maka siapa pun berhak untuk mencari tahu kebenarannya tanpa ada sekat atau batasan sehingga informasi yang diterima oleh warganet akan berimbang dan dapat meminimalkan berita bohong atau hoax.

Diskusi antarwarganet setelah munculnya meme politik yang mengkritik rencana pemindahan ibu kota tercermin dalam kolom komentar pada akun Instagram @fakartun sebagai berikut: 


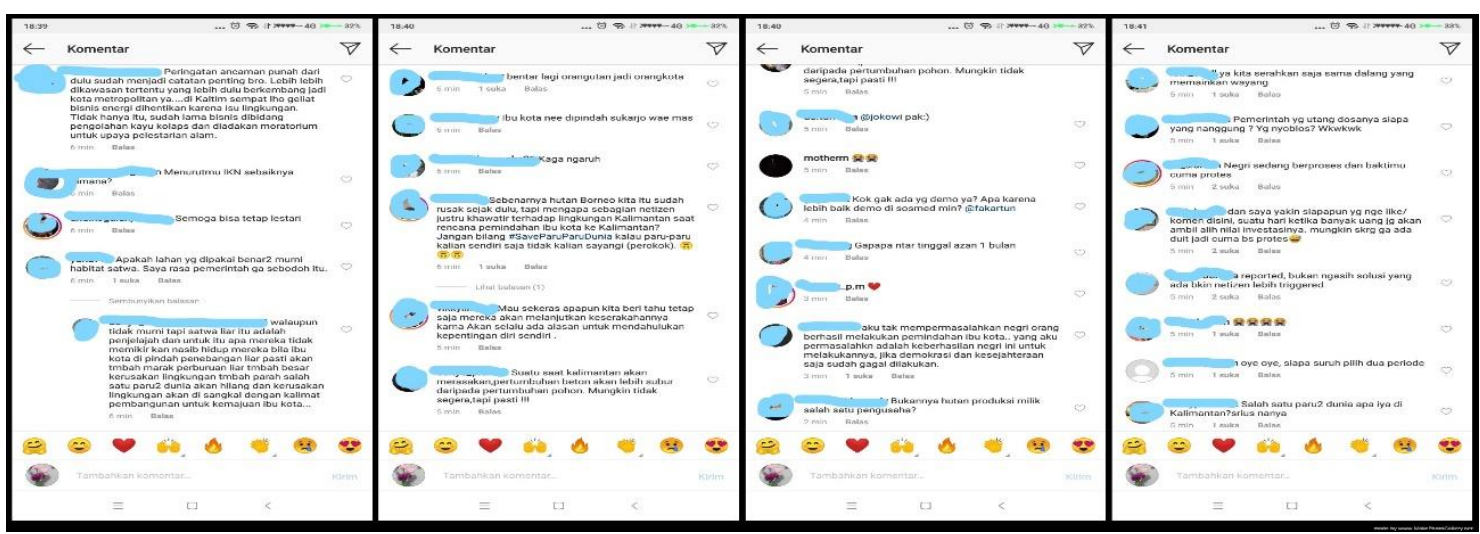

Gambar 2: kolom komentar di Instagram @fakartun (representasi ruang diskusi)

Pada kolom komentar di atas terlihat ada sebuah ruang diskusi yang terbentuk setelah kemunculan meme pascapengumuman pemindahan ibu kota oleh Presiden Republik Indonesia. Warganet bebas berpendapat tentang rencana tersebut, ada yang secara terang-terangan mendukung, menghujat, tetapi tidak sedikit yang netral atau bahkan belum menentukan sikap, seperti pada contoh komentar berikut "apakah lahan yang dipakai benar-benar murni habitat satwa, saya rasa pemerintah ga sebodoh itu" dari tuturan terebut salah satu warganet secara tidak langsung tidak menolak rencana pemerintah untuk memindahkan ibu kota ke Kalimantan. Sangat bertolak belakang dengan tuturan "suatu saat Kalimantan akan merasakan pertumbuhan beton akan lebih subur daripada pertumbuhan pohon" tuturan ini dilatarbelakangi dengan adanya rencana pemindahan ibu kota ke Kalimantan yang lahannya sebagian masih hutan hijau dan dapat dibayangkan jika pemindahan tersebut terjadi maka tidak dapat dipungkiri pohon yang sudah ada akan segera diganti dengan tiang-tiang beton yang menjulang tinggi, kokoh sekokoh niat pemindahan ibu kota dengan alasan apa pun. Ada juga komentar dari warganet yang hanya menuliskan "kaga ngaruh" melalui tuturan ini tidak terlihat keberpihakan warganet. Belum ada sikap yang jelas ditunjukkan apakah setuju atau menolak terhadap rencana pemindahan ibu kota ke Kalimantan.

\section{SIMPULAN}

Meme yang sudah ditampilkan dalam pembahasan sebagai representasi data dapat disimpulkan bahwa tanda-tanda baik visual dan tanda verbal dapat mengomunikasikan sebuah maksud dari penciptaan sebuah meme. Meme yang pada umumnya bersifat satir yang muncul pascapengumuman "pemindahan ibu kota" merupakan upaya dari warganet sebagai bentuk reaksi atas aksi yang ditimbulkan oleh pemerintah yaitu pengumuman resmi pemindahan ibu kota. Hal ini sekaligus menjawab pertanyaan penelitian tentang bagaimana tanda dan makna yang muncul dalam meme merupakan bentuk perkembangan berpikir kritis terhadap sebuah kebijakan pemerintah. Pengemasan meme secara sederhana, lugas, dan lucu ternyata mampu menjadi alat bagi warganet untuk menuangkan berbagai reaksi secara bebas di ruang siber dan mencari kebenaran atas isu-isu yang ada, sedangkan penggambaran berpikir kritis warganet tercermin melalui ikon, simbol, dan indeks yang muncul dalam meme tersebut.

Meme politik dengan tema "pemindahan ibu kota" memberikan beberapa tanda yang sifatnya sebagai sebuah kritikan dari warganet pada kebijakan pemerintah melaui ruang siber. Hal ini terlihat jelas pada tampilan gambar dan teks tuturan dalam meme 
tersebut yang mengimplikasikan bahwa ada kekhawatiran tersendiri baik penduduk Kalimantan maupun penduduk Jakarta, terlebih dimunculkan juga gambar orang hutan, sebagai seekor hewan pun ada rasa takut kehilangan tempat tinggal. Dengan demikian, berdasarkan pemunculan meme merupakan tanda yang diberikan warganet bahwa dengan rencana "pemindahan ibu kota" ada yang sedang tidak baik-baik saja, banyak hal yang masih harus dipersiapkan. Selain itu, akan ada pihak-pihak yang secara langsung terkena dampaknya.

Selain itu, data tidak hanya terputus hanya pada gambar meme itu sendiri (gambar dan tulisan dalam meme) tetapi juga berlanjut dalam komentar sebagai cerminan munculnya ruang diskusi di media siber. Melalui ruang komentar warganet bebas berdiskusi, menyampaikan pendapat baik yang bersifat pro dan kontra atau yang belum menentukan sikap. Di ruang komentar ini ada pihak yang mendominasi yaitu pihak yang memiliki pemikiran sejalan dengan si pemilik dan pembuat meme tersebut. Ada juga pihak yang bertindak sebagai determinan karena memilki pemikiran yang berlawanan dengan meme yang muncul.

Penelitian ini mengimplikasikan bahwa perkembangan dunia siber sudah semakin meluas seiring dengan perkembangan teknologi saat ini. Hal ini memberikan ruang tersendiri bagi warganet untuk dapat berekspresi, berkreasi, serta bebas berpendapat bahkan mengkritisi sesuatu. Begitupun juga dalam mencari informasi warganet bebas berselancar mencari, membandingkan, bahkan menilai sesuatu tanpa ada sekat sehingga dapat meminimalkan diri terjebak dalam berita bohong atau hoax.

\section{DAFTAR PUSTAKA}

Berger, P. (1997). Redeeming laughter: Comic dimension of human experience. Berlin, Jerman: Walter de Gruyter\& Co.

Dahlberg, L. (2006). Computer-mediated communication and the public sphere: Acritical analysis. Journal of Computer Mediated Communication, 7(1). https://doi.org/https://doi.org/10.1111/j.1083-6101.2001.tb00137.x

Dawkins, R. (2006). Selfish gene. In New Scientist (anniversar, Vol. 214). https://doi.org/10.1016/S0262-4079(12)61286-X

Hoed, H. B. (2011). Semiotik dan dinamika sosial budaya. (Kedua). Depok: Komunitas Bambu.

Ku, K. Y., Kong, Q., Song, Y., Deng, L., Kang, Y., \& Hu, A. (2019). What predicts adolescents' critical thinking about real-life news? The roles of social media news consumption and news media literacy. Thinking Skills and Creativity, 33, 100570.

Liszka, J. J. (1994). A general introduction to the semeiotic of charles sanders peirce. Bloomington: Indiana University Press.

Ross, A. S., \& Rivers, D. J. (2019). Internet memes, media frames, and the conflicting logics of climate change discourse. Environmental Communication, (January). https://doi.org/10.1080/17524032.2018.1560347

Saifullah, A. R. (2016). Issues of terrorism on the internet in the wave of 
democratization of post-reform Indonesia: A semiotic analysis. Indonesian Journal of Applied Linguistics, 5(2), 307-315. https://doi.org/10.17509/ijal.v5i2.1354

Saifullah, A. R. (2019). Semiotik dan kajian wacana interaktif di internet. (Pertama). Bandung: UPI Press.

Shifman, L. (2007). Humor in the age of digital reproduction: Continuity and change in internet based comic texts. International Journal of Communication 1, 204.

Shifman, L. (2013). Memes in a digital world: Reconciling with a conceptual troublemaker. Journal of Computer-Mediated Communication.

Sudarsono, S. C. (2017). Representasi masyarakat Indonesia yang tecermin melalui ketidakjujuran dalam wacana humor meme awas itu hoax. Prosiding Konferensi Linguistik Tahunan Atma Jaya, 15, 21-25.

Susanti, E. (2015). Hegemony of the social media twitter about national issues in Indonesia and its implications to the discourse analysis subject in colleges. TARBIYA: Journal of Education in Muslim Society, 2(1). https://doi.org/10.1017/CBO9781107415324.004

Upcoming LIVE. (2019). Presiden Jokowi mengumumkan ibu kota baru. Retrieved from https://www.youtube.com/watch?v=196taABMSN8

Zubaidah, N., \& Ardelia, I. (2018). A discourse analysis of memes. Getsempena English Education Journal, 5(2), 58-64. 